\title{
Improving Participation of College Female Students in Physical Activities
}

\author{
Sun Fenglin \\ Department of Physical Education, Beijing WuZi University, Beijing, China \\ sunfenglinna@sina.com
}

\begin{abstract}
There are many problems for college female students to participate in physical activities, such as being passive in physical activities, lack of after-school activities, outdoor activities, etc. Many factors affect college female students' sports participation: at the level of students, their participation in sports is greatly influenced by their physiological limitations and psychological negative emotions, such as anxiety, shyness, rebellion; at the school level, their participation in sports is mainly influenced by teaching content, teaching organization, teachers' quality, teaching evaluation mechanism, and the facilities. In view of these problems, many measures can be taken to push college female students to engage in physical activities. These measures include improving the course selection mechanism, updating teaching ideas, improving the assessment mechanism, increasing interior space, cultivating sports organizations, etc.

Index Terms - college female students, sports activities, problems, countermeasures.
\end{abstract}

\section{Introduction}

In recent years, under the guidance of "health first" thought, great achievements have been made in sports. However, the development of sports is uneven. There is a big difference between boys and girls in the sports thought, sports awareness, and sports habits. Girls are an important part of college sports crowd, and they are important carrier and special group of University Sports. They are 18 22 years old, whose body is in a growth phase. And physical fitness is important for this group. How to improve university female students' sports consciousness and improve the interest of university female students' physical education and fitness, eventually achieve the objective of lifelong physical education, become a very urgent matter.

\section{Problems of College Female Students in Physical Activities}

At present, China's health condition of female students in colleges and universities is poor. There is a big gap for participation awareness between boys and girls. A large proportion of female college students are reluctant to participate in significant sports, and gym classes become a burden for them. These can be mainly reflected as not paying attention in class, lack of confidence, dismissing leave, completing task reluctantly, fewer extracurricular activities to participate in, and being afraid of dirty sweat, etc. From the analysis of these factors affecting the college female students' participation in sports, the paper is aimed at finding effective measures to change this situation.

\section{A. Sports in class}

Because most of female college students don't like sports, they get a poor performance on the physical education activities; in return, they are more passive in the sports activities.

There are many problems in physical education in colleges, such as teaching methods, teaching mode, teaching philosophy, teaching course, teaching objectives, teaching content, and so on.

\section{B. Sports after class}

First, a lot of girls do not have the consciousness of physical exercises and sports habits, so they find few extracurricular activities to participate in physical exercise.

Second, no one regularly organize extracurricular activities, and it is difficult to get organizations to support in the physical activities, and students' sports organizations are not enough to provide help for sports activities in colleges.

\section{Outdoor sports}

Female college students like entertainment, fun activities, and do not like confrontational sports. And boys dominate the outdoor sports space, such as basketball courts, soccer fields, tennis courts and so on. In comparison, girls like aerobics, badminton, table tennis and other indoor activities. However, they get fewer training opportunities, thus it is very difficult for female college students to form the exercise habits.

\section{Sports off campus}

Most of the female students in the school are rarely engaged in physical activities. At weekends or during summer vacations, very few girls participate in sports activities. On the one hand, because of their own laziness, they are not willing to take physical exercise; On the other hand, during the holidays, it is difficult to get enough opportunities to do physical exercise. Because of both the subjective and objective reasons, they lead to this situation that girl group take part in physical activities outside school at the comparatively low rates.

\section{Factors Influencing Sport Participation of College Female Students}

\section{A. At student level}

\section{1) Biological factors}

The developmental period for girls is from the age of 17, 18 to 23 years old, which increase subcutaneous fat girls. Due to the stimulation of the pituitary towards gondola growth, the 
secondary sex characteristics emerge. The growth rate of height and weight begin to decline, improvement of physical quality of natural growth become slow. Within this period, due to physiological changes as a result of discharging the adverse impact on the campaign, students don't want to do any activities. Obesity increases the inertia of each part of the body, and reduces contraction speed and explosive power, and the flexibility of coordination of movements is destroyed. Coupled with the increase in body weight, the physiological changes of female college students make themselves reduce physical exercises.

\section{2) Psychological factors}

There are many psychological barriers for female college students to participate in sports.

First, being passive in sports. Their main motives are to pass the physical education examinations, and they are lack of a correct understanding of physical exercises;

Second, being anxious. Some female students is shy by nature, so they are unwilling or even afraid of participating with considerable perseverance, courage in competitive sports activities. In general, they are more willing to be spectators in physical education teaching process. When it comes to a certain level of action, they often show the emotions of anxiety, stress, uncertainty, fear, lack of confidence, and so negative and unhealthy psychological phenomena emerges.

Third, being afraid of difficulties. Nowadays more and more college students are in lack of the willpower of self-care and tenacious struggle, and the hard working spirit. Therefore, they need to overcome the physical fear, such as fear of wind, sun, rain, fear of sweating, being tired, being afraid of confrontation, and so on.

The last, shyness. Due to the physiological development of female university students, they become very sensitive, very concerned about teachers, other students' views and evaluations. When they are learning a new action or completing a difficult action, especially in front of a male teacher and male students, normally they would feel embarrassed.

The fifth, rebellion. Because of poor teaching methods of physical education teachers or teaching, female college students show backlash in sports.

\section{B. At the school level.}

\section{1) Course content.}

All physical education courses offered at colleges are largely different, but girls only like to participate in interesting, non-confrontational, elegant sports. When they have to choose the sports which are compulsory, they will feel bored. The track is a typical example in that it gradually fades out of physical education course is an indisputable reality. This may be the result of both students' request and the consideration of sport reform. The curriculum content, course selection, course structure need to be improved to meet the needs of female college students.

\section{2) Teaching organization.}

Teaching organization means the interaction between teachers and students in teaching activities, or common activities between teachers and students in the combination of people, processes, spatio-temporal relations forms. Class teaching is used in the current university to teach the course of physical education, which has a certain advantage. However, in the case of teaching female students, a single organization restricts the students' learning.

First, the students' initiative and independence are subject to certain restrictions;

Second, it is not conducive to the cultivation of students' spirit of exploration, creativity and hands-on skills;

Third, it is difficult to fit more content and methodology in teaching activities;

Forth, the teacher's instruction is facing the whole class, but it is difficult to cater for individual differences.

\section{3) Teaching philosophy.}

Teachers are the performers of the teaching task and they are regulators in the process of teaching. Their teaching, teaching philosophy, teaching methods, and the teaching of literacy are deeply affecting students' sport participation awareness and behavior. The teachers of female students should make full use of various means to increase female participation in physical education teaching process. They needn't to let them be the audience, needn't to let them free rein, with the "shepherd style" teaching.

\section{4) Evaluation mechanisms.}

In the course of female students' evaluation, participation should be an important criterion, which is emphasized to combine application of process evaluation and summative evaluation, and is greatly emphasized on evaluation of the process to change the passive way college students take in physical education. Evaluation for the improvement of girls' ability in physical education is very important.

\section{5) Facilities.}

The shortage of sports equipment and sports space seriously restrict female students' sports participation. In view of college sports equipment and space, although there is no such "men's only" label, in fact, they are occupied mostly by male students. Girls' favourite sports often can't be carried out for lack of equipment and space, which directly restrict the students' extracurricular sports activities, thus make it difficult for internal and external integration of physical education class. Girls are more and more passive in extracurricular activities, which is a major cause of the declining of college students' physical quality.

\section{Countermeasures}

\section{A. Perfecting course selection mechanism}

Only when reduced the content of competitive projects, increase the entertaining high fitness value, effectiveness, and synchronizes with the fitness of the community project, the sporting activities can meet the physiological, psychological 
needs for the lifelong fitness of female university students. Proceeding from the interest of female university students, student-oriented entertainment, settings become diversified in physical education lessons and entertainment, which enable female students to be healthy in the entertainment, so as to change their state of health and enhance their lifelong physical awareness. Girls normally prefer to yoga, aerobics, badminton, table tennis, and dance and so on. We can choose to add some social popular women's favourite projects, such as shaping, Latin dance, street dance, belly dancing, folk dancing, and so on, to meet students' individual needs and desires. Female college students are close to life, and they can walk in the forefront of health, entertainment, and increase their selfconfidence, enhance fashion sense, which contribute to deepen the transformation in the direction of the reform. Colleges need to increase hardware facilities, and encourage the formation of sports associations, make students actively participate in social activities and extra curriculum activities, no matter they are internal or external sports.

\section{B. Improving teachers' professional quality}

Teachers play a vital role in promoting girls' participation in physical education. Colleges need to take measures to improve teachers' teaching ideas to strengthen their responsibility with the premise of promoting teachers' effectiveness, and also need to make diverse targets to improve teaching methods. Teachers need to take full advantage of their professional skills to meet the diverse needs of female students according to their psychological and physiological characteristics.

\section{Modifying assessment mechanisms}

Female students need to be guided and supervised to participate in physical exercise actively. It is necessary to reform physical education evaluation approach and methodology. The combination of organization and guide can be effective in increasing girls' sports participation. Professor Zhang Hongtan's teaching methodology of technical fitness still has a positive meaning, but the participation of many girls who like physical activities is restricted. They don't want to sweat out during the class, so the increase of physical fitness of female students is restricted. University students' interest in physical education must be guided and forced in order to develop female sports participation.

\section{Adding indoor gymnasium facilities.}

Because of the realities that college female students prefer indoor sporting activities, the following measures need to be taken to increase the physical activities of female college students. First, colleges need to expand women's indoor space actively, increase their active use of indoor sports facilities and upgrade existing space, provide better sport services for female students. Second, the new expanded indoor sports space, indoor activity space should be increased. Third, the boys can be urged to take outdoor activities, and leave more indoor space for girls.

\section{E. Cultivating girls sports organization}

Sports organizations can be managed by specialized people to raise the enthusiasm of girls' sports participation effectively and to promote sustainability of their participation in sporting events. On the basis of physical education we can organize more sports associations for girls, such as aerobic Club, in-line Skating Association Club, hip-hop Club, Badminton Club, ballroom dance club, table tennis club, Yoga Club, basketball club, etc. These sports associations can encourage female students to participate in physical activities regularly.

\section{F. Organizing sports competitions}

Teachers should organize enough sports competitions in spare time at colleges, such as basketball, soccer, badminton competitions, tennis, volleyball, track and field competitions. Through active participation in sports competitions, the enthusiasm and motivation of female students can be inspired. To accept effective physical training, they may actively ask for help to get guidance from teachers when they are doing extracurricular sports activities. In this way, female students' physical fitness can be strengthened, and their friendship can also be enhanced.

\section{Conclusion}

There are some problems for college female students to participate in physical activities, such as being passive in physical activities, lack of after-school activities, outdoor activities, etc. Many factors affect college female students' sports participation: at the level of students, their participation in sports is greatly influenced by their physiological limitations and psychological negative emotions, such as anxiety, shyness, rebellion; at the school level, their participation in sports is mainly influenced by teaching content, teaching organization, teachers' quality, teaching evaluation mechanism, and the facilities. In view of these problems, many measures can be taken to push college female students to engage in physical activities. These measures include improving the course selection mechanism, updating teaching ideas, cultivating sports organizations improving the assessment mechanism, increasing interior space.

\section{References}

[1] Wang Zeshan, " a lifelong study of sports”, Journal of Beijing Sport University, vol. 8, no. 2, pp. 23-25, March 2001.

[2] Zhou DengSong, Sports Modernization Over view, 8eijing: Beijing Sport University Press, 2008.

[3] Zhou DengSong, Comprehensive Study of Capital Institute of Physical Education Modemization-Oeneral Project Report, Beijing: Beijing Sport University Press, 2009, 1: 7 1-76(In Chinese).

[4] Zhou DengSong, Comprehensive Study of Capital Institute of Physical Education Modernization termination-Subproject Report, Beijing: Beijing Sport University press, 2009, 1: 61—86(In Chinese).

[5] Sisson, S. B., (2005). College students understanding of physical activities. American Journal of Health Studies. 34(2), 1-2.

[6] Sidman, C. L., D Abundo, M. L. \& Hritz, N. (2009) Exercise selfefficacy and perceived wellness among college students in a basic studies course. International Electronic Journal of Health Education. 12:158-174. 
[7] Lin Song, "lifelong physical education and sports interest, sports ability", Journal of physical education, vol. 4, no. 4, pp. 15-35, March 2005.

[8] Zhang Yi, "analysis of secondary school students sports culture area difference", Journal of Institute of Shenyang, vol. 7, no. 3, pp.46-58, May 2008.

[9] Qi Yi, "on the teaching reform of physical education from the social process", Journal of Beijing Sport University, vol. 9, no. 1, pp.36-56, Feb 2009.

[10] Maxwell, J. A. (1996). Qualitative research design: An interactive approach. Sage Publications. Thousand Oaks: CA .McArthur, L. H. \& Raedeke, T. D. (2008). Race and sex differences in college student physical activities correlates. American Journal of Health Behaviour. 4(1),89-93.
[11] Merriam, S. B. (2002). Qualitative research in practice: Examples for discussion and analysis. Josses-Bass. H. Simpson, Dumb Robots, 3rd ed., Springfield: UOS Press, 2004, pp.11-21.

[12] M. King and B. Zhu, "Gaming strategies," in Path Planning to the West, vol. II, S. Tang and M. King, Eds. Xian: Jiaoda Press, 1998, pp. 168178 .

[13] Mills, G. (2003). Action research: A guide for the teacher researcher (2nd ed.). Upper Saddle River, NJ: Pearson Education.

[14] NASPE - National Association for Sport and Physical Education \& American Heart Association. (2006). 2006 Shape of the Nation Report: Status of Physical Education in the USA. Reston, VA: National Association for Sport and Physical Education

[15] Phillips, K. R., Revels, M., \& Ujamaa, D. (2010). Contribution of the school environment to physical fitness in children and youth. Journal of Physical activities and Health.7, 321-332. 